\title{
Anomaly Detection in Foetus using Ultrasound Invest Processing
}

\author{
Khan Sumaiya \\ Department of Computer Science and Information \\ Technology \\ Dr. Babasaheb Ambedkar Marathwada University \\ Aurangabad-431001, Maharashtra, India
}

\author{
S.S. Kawathekar, $\mathrm{PhD}$ \\ Department of Computer Science and Information \\ Technology \\ Dr. Babasaheb Ambedkar Marathwada University \\ Aurangabad-431001, Maharashtra, India
}

\begin{abstract}
Ultrasound one of the main and popular medical imaging technology that can help a physician to check, diagnose and treat medical conditions. Anomaly (congenital abnormalities) is a common problem occurred in many new-borns. Anomalies if detected early can be very helpful in giving rational treatment of the new-born. Unidentified or untreated anomaly in the foetus can deteriorate the quality of life and can lead to loss of life. The latest advancements in ultrasound invest processing permits individuals to detect these abnormalities more efficiently and treat them more effectively. Some are Contrast-Enhanced Ultrasound Imaging, Super-Resolution Ultrasound Imaging, Sonoporation, HighIntensity Focused Ultrasound, 4-D Ultrasound, Molecular Ultrasound, 5-D Ultrasound, and Radiomic Ultrasound. Present-day ultrasound machines are completely computerized, which not only improves the signal to noise ratio of the arriving echoes but also offer great potential to the machine's efficiency with respect to beam formation, signal processing, image display and archiving. The present review mainly focuses on the latest progress in ultrasound diagnosis, various patents filled, common challenges in ultrasound processing and proven techniques to overcome those challenges.
\end{abstract}

\section{Keywords}

Ultrasound, Anomaly detection, Recent advancements, Ultrasound challenges, Patent filled.

\section{INTRODUCTION}

The expression "ultrasound "applies to all acoustic energy with a frequency above human hearing (20,000 hertz or 20 kilohertz). Diagnostic sonography (ultrasonography) is an ultrasound-based diagnostic imaging strategy used to see the subcutaneous body structures including ligaments, joint spaces, and inside organs for conceivable pathology. Figure 1 shows the image of an ultrasound. Sonography is a viable instrument for imaging the body tissues which are delicate parts. Sonographers normally utilize a hand-held tool (called a transducer) that is put legitimately on and moved above the patients' skin for checking the structure of internal organs [1]. The use of ultrasound in medicine started in the fifties of the last century. First was presented in the obstetrics, and after that in every one of the fields of the medicine (the general stomach diagnostics, the diagnostics in the field of the pelvis, cardiology, ophthalmology, and orthopaedics, etc.). From the clinical viewpoint, the ultrasound has very useful due to its non-invasive, great representation attributes, and generally simple administration [2].

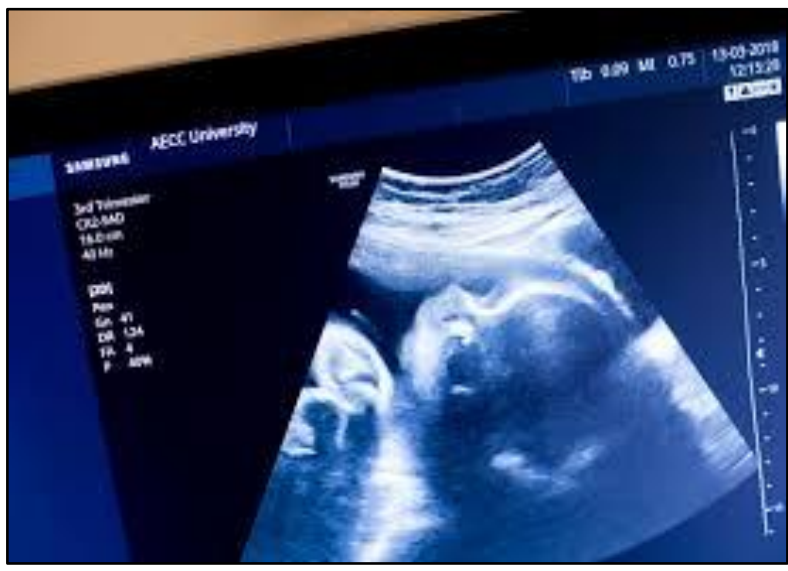

Figure 1: The image of an ultrasound

\subsection{Anomaly Detection}

Ultrasound technique is utilized to check the gestational age to perform fetal measurements for the timely detection of abnormalities. Congenital abnormalities happen in $3 \%$ of all infants, Congenital anomalies such as structural abnormalities, chromosomal irregularities, and disorders of metabolism are turning into the most significant reason for perinatal mortality (about a fourth of every single perinatal demise) in the nations of Europe. Enduring kids with physical, mental, and social debilitations are a huge weight on wellbeing and social services [3- 5]. Prenatal ultrasonography screening for fetal abnormalities has turned into a standard method of prenatal care; it is a diagnostic technique that is noninvasive, modest, and promptly acknowledged by pregnant ladies. Improvement in the innovation, skills, and expertise of ultrasonography examiners has prompted the increased identification of malformation $[4,5]$. It is generally acknowledged that most anomalies can be detected earlier. In this regard, major abnormalities have been divided into three types because of the likelihood of their detection rate by 11 -fourteenth weeks' ultrasound. The first group consists of abnormalities that can be effectively detected in the 1 st trimester, for example, anencephaly, $2^{\text {nd }}$ group contains anomalies that uncover ultrasonography signs later in gestation and have no probability of early assessment, for example, hypoplasia of cerebellum. The $3^{\text {rd }}$ abnormalities can be detected in the first trimester with careful assessment utilizing recent advanced devices. This group of anomalies includes spina bifida occulta, skeletal dysplasia, and a few sorts of cardiovascular deformities, which some of the time should be inspected utilizing transvaginal ultrasound $[6,7]$. 


\section{THE NEED FOR EARLY ANOMALY DETECTION}

Anomaly if detected early can be very helpful in giving rational treatment to the new-born. Unidentified or untreated anomaly in the foetus can deteriorate the standard of life \& may lead to death. Early diagnosis of these abnormalities is an important key for management. Screening in the first and early second trimester and early recognition of major birth defects will prompt early choices of pregnancies end. Besides, doing it before the sixteenth gestational week brings the benefit of early termination before ladies feel the developments of the fetus. This is significant for ladies, particularly in societies in which beliefs strongly affect social life rules. Besides, the early end of pregnancy has physical and physiological benefits for ladies and their families contrasted and late end [8].

\section{ULTRASOUND DETECTION MECHANISM}

The image formation ultrasound machine occurred in 3 steps which are explained below in figure 2 .

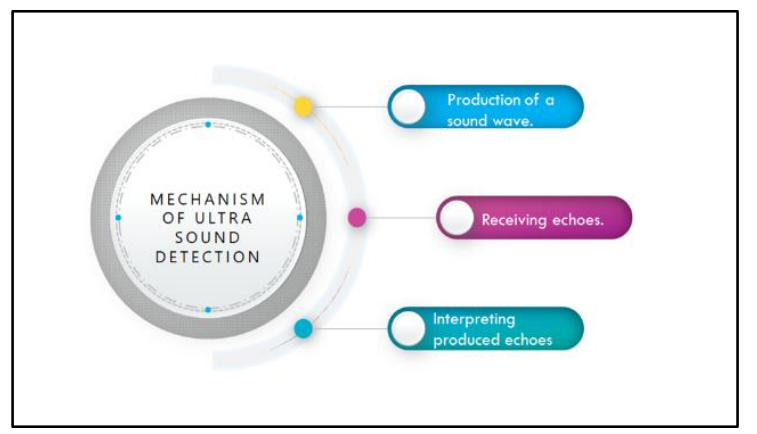

Figure 2: Schematic representation of the mechanism of ultrasound.

\subsection{Sound Wave Production}

A sound wave is created by a piezoelectric transducer placed in a probe. Powerful, short electrical beats which come from US machine causes transducer to ring at the desired frequency. The frequencies are in between $2 \& 18 \mathrm{MHz}$ range. The focusing of sound is done not only by the state of a transducer, a lens before the transducer, or complex groups of control beats from the US scanner (Beamforming). Sound waves which are arc-shaped from the of the transducer is formed by these focusing forms. The wave passes into the body and arrives at focus at a necessary depth. Materials on the transducer face empower the transmission of sound proficiently into the body. Moreover, a water-based gel is kept in the skin of the patient and the probe. The wave of sound is passed from between various tissue layers. Especially where there are changes in density in the body: for example, blood cells in the blood, little structures in organs, and so on. A part of the reflections come back to the transducer.

\subsection{Receiving the Echoes}

The arrival of the sound wave to the transducer results in a similar which takes place while sending, with the exception it is in reverse. The arrival sound wave vibrates the transducer, the transducer transforms the vibrations into electrical pulses that travel to the ultrasonic scanner where they are processed and changed into a computerized picture.

\subsection{Forming the Image}

The sonographic scanner must decide three things from each got received echo.

1. How long it took the echo to be received when the sound was transmitted.

2. From this the focal length of the phased array is deduced, allowing a clear picture of that echo at that depth.

3. How powerful the echo was. It could be noticed that sound wave isn't a click, but a pulse with a transporter frequency. When the ultrasonic scanner decides these three things, it can find which pixel in the picture to illuminate and to what intensity it is $[9,10]$.

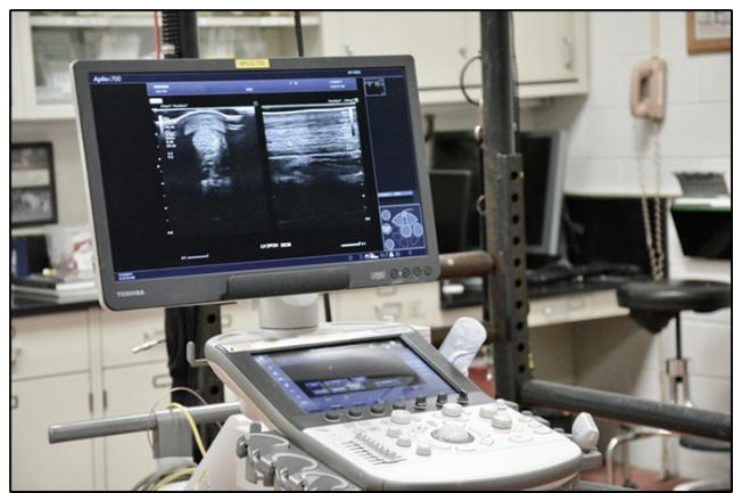

Figure 3: Mechanism of ultrasound technique.

\section{DIFFERENT TYPES OF \\ CONGENITAL ANOMALIES}

There various types of congenital anomalies that can occur due to various reasons, some of the most prevalent disorders which affect the cardiovascular, central nervous, Gastrointestinal, Musculoskeletal systems, etc. Along with their prevalence are discussed below in table 1 .

\subsection{Different Types of Congenital Anomalies According to W.H.O [11]}

Table 1. Different types of congenital Anomalies according to W.H.O

\begin{tabular}{|c|c|c|c|}
\hline Sr.no & Name of disease/disorder & $\begin{array}{c}\text { System/organ } \\
\text { affected }\end{array}$ & $\begin{array}{c}\text { Cases } \\
\text { per } \\
\text { birth }\end{array}$ \\
\hline 1 & Anencephaly & $\begin{array}{c}\text { Central nervous } \\
\text { system }\end{array}$ & $\begin{array}{c}1 \text { in } \\
4859\end{array}$ \\
\hline 2 & $\begin{array}{l}\text { Spina bifida without } \\
\text { anencephaly }\end{array}$ & $\begin{array}{c}\text { Central nervous } \\
\text { system }\end{array}$ & $\begin{array}{c}1 \text { in } \\
2858\end{array}$ \\
\hline 3 & Encephalocele & $\begin{array}{c}\text { Central nervous } \\
\text { system }\end{array}$ & $\begin{array}{c}1 \text { in } \\
12,235\end{array}$ \\
\hline 4 & Common truncus & $\begin{array}{c}\text { Cardiovascular } \\
\text { system }\end{array}$ & $\begin{array}{c}1 \text { in } \\
13,876\end{array}$ \\
\hline 5 & $\begin{array}{c}\text { Transposition of great } \\
\text { arteries }\end{array}$ & $\begin{array}{c}\text { Cardiovascular } \\
\text { system }\end{array}$ & $\begin{array}{c}1 \text { in } \\
3333\end{array}$ \\
\hline 6 & Tetralogy of Fallot & $\begin{array}{c}\text { Cardiovascular } \\
\text { system }\end{array}$ & $\begin{array}{c}1 \text { in } \\
2518\end{array}$ \\
\hline 7 & $\begin{array}{c}\text { Atrioventricular septal } \\
\text { defects }\end{array}$ & $\begin{array}{c}\text { Cardiovascular } \\
\text { system }\end{array}$ & $\begin{array}{c}1 \text { in } \\
2122\end{array}$ \\
\hline 8 & $\begin{array}{l}\text { Hypoplastic left heart } \\
\text { syndrome }\end{array}$ & $\begin{array}{c}\text { Cardiovascular } \\
\text { system }\end{array}$ & $\begin{array}{c}1 \text { in } \\
4344\end{array}$ \\
\hline 9 & Esophageal & Gastrointestinal & 1 in \\
\hline
\end{tabular}




\begin{tabular}{|c|c|c|c|}
\hline & $\begin{array}{c}\text { atresia/tracheoesophageal } \\
\text { fistula }\end{array}$ & defects & 4608 \\
\hline 10 & $\begin{array}{c}\text { Rectal and large intestinal } \\
\text { atresia/stenosis }\end{array}$ & $\begin{array}{c}\text { Gastrointestinal } \\
\text { defects }\end{array}$ & $\begin{array}{r}1 \text { in } \\
2138\end{array}$ \\
\hline 11 & $\begin{array}{l}\text { Reduction deformity, upper } \\
\text { limbs }\end{array}$ & $\begin{array}{c}\text { Musculoskeletal } \\
\text { defects }\end{array}$ & $\begin{aligned} 1 \text { in } \\
2869\end{aligned}$ \\
\hline 12 & $\begin{array}{l}\text { Reduction deformity, lower } \\
\text { limbs }\end{array}$ & $\begin{array}{c}\text { Musculoskeletal } \\
\text { defects }\end{array}$ & $\begin{array}{c}1 \text { in } \\
5949\end{array}$ \\
\hline 13 & Gastroschisis & $\begin{array}{l}\text { Musculoskeletal } \\
\text { defects }\end{array}$ & $\begin{array}{r}1 \text { in } \\
2229\end{array}$ \\
\hline 14 & Omphalocele & $\begin{array}{c}\text { Musculoskeletal } \\
\text { defects }\end{array}$ & $\begin{array}{c}1 \text { in } \\
5386\end{array}$ \\
\hline 15 & Diaphragmatic hernia & $\begin{array}{c}\text { Musculoskeletal } \\
\text { defects }\end{array}$ & $\begin{array}{c}1 \text { in } \\
3836 \\
\end{array}$ \\
\hline 16 & Cleft palate without cleft lip & $\begin{array}{c}\text { Orofacial } \\
\text { defects }\end{array}$ & $\begin{array}{c}1 \text { in } \\
1574\end{array}$ \\
\hline 17 & $\begin{array}{l}\text { Cleft lip with and without } \\
\text { cleft palate }\end{array}$ & $\begin{array}{c}\text { Orofacial } \\
\text { defects }\end{array}$ & $\begin{array}{l}1 \text { in } \\
940\end{array}$ \\
\hline 18 & $\begin{array}{c}\text { Anophthalmia/microphthalmi } \\
\text { a }\end{array}$ & Eye defects & 1 in \\
\hline 19 & Trisomy 13 & $\begin{array}{l}\text { Chromosomal } \\
\text { anomalies }\end{array}$ & $\begin{array}{c}1 \text { in } \\
7784\end{array}$ \\
\hline 20 & $\begin{array}{c}\text { Trisomy } 21 \text { (Down } \\
\text { syndrome) }\end{array}$ & $\begin{array}{l}\text { Chromosomal } \\
\text { anomalies }\end{array}$ & $\begin{array}{l}1 \text { in } \\
737\end{array}$ \\
\hline 21 & Trisomy 18 & $\begin{array}{l}\text { Chromosomal } \\
\text { anomalies }\end{array}$ & $\begin{array}{c}1 \text { in } \\
3788 \\
\end{array}$ \\
\hline
\end{tabular}

abnormalities is performed; there is wide variation in both skills of staff and quality of the equipment; and some fetus are hard to check maternal habitus, depletion in liquor volume or continuous troublesome position. It is critical to know about the impediments of prenatal ultrasound and to be completely honest if challenges are experienced in the ultrasound assessment of fetal anomaly. Regular difficulties experience in ultrasound is clarified underneath in figure 5.

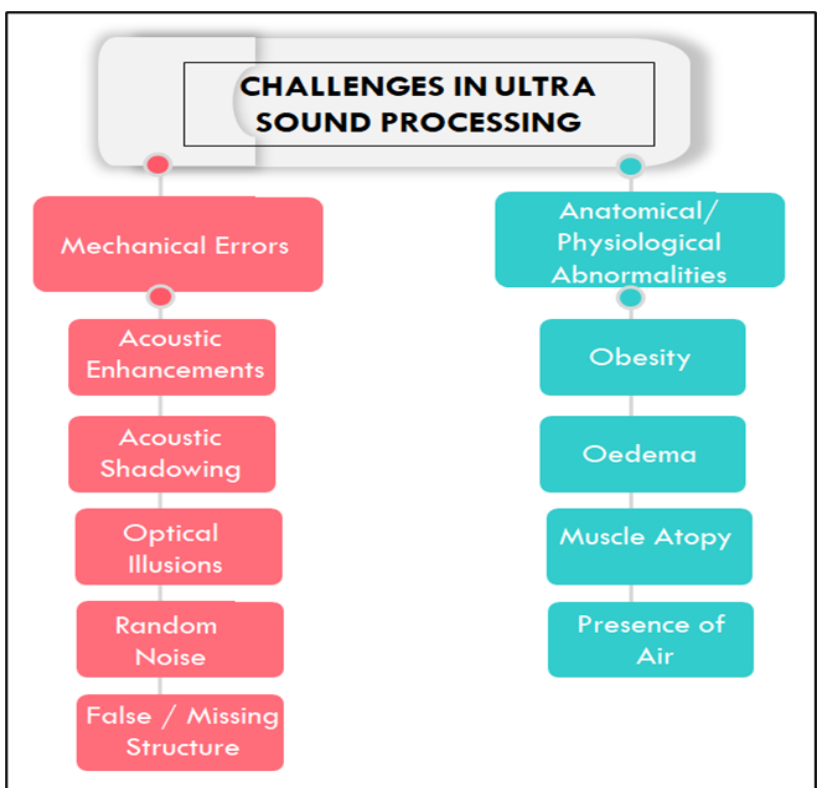

\section{CAUSES OF CONGENITAL MALFORMATIONS}

There are various causes of congenital abnormalities following in Figure 4 are the most common causes of congenital malformations [12].

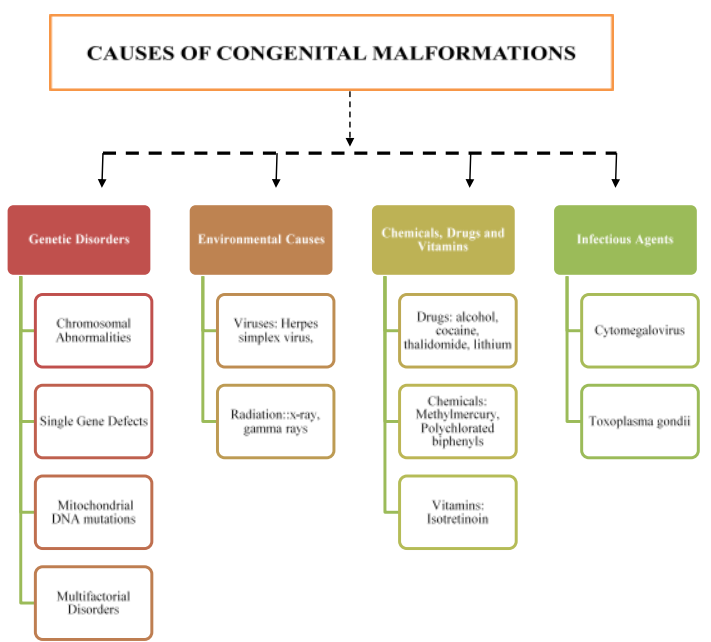

Figure 4: Causes of various congenital abnormalities.

\section{VARIOUS CHALLENGES IN ULTRASOUND PROCESSING \& PROVEN TECHNIQUES TO OVERCOME [13, 14].}

Even though routine screening for fetal abnormalities is undoubtedly very successful in general, but there are impediments to the abilities of both the procedure and the operators to identify each anomaly. There are a few explanations behind this: not all irregularities (for example some heart, gastrointestinal and renal irregularities) are seen at 20 weeks when the normal ultrasound assessment of

\subsection{Mechanical Errors}

Various mechanical errors can arise during the process of ultrasound detection some of the most frequent errors are discussed below.

\section{- Optical Illusion}

Illusions may be classified as illusions of sensation, perception, and image formation. They represent changes in the look of reality because of the process of image formation and can result in mistakes in interpretation.

\section{- Random Noise}

Noise deteriorates the quality of an Ultrasound image and frequently appears as low-amplitude echoes in echo lucent areas. The start of random noise is extensive and frequently includes extreme gain and other changes in machine settings. A general source of noise in the operating theatre is electrocautery. Ultrasound machines are many times fitted with filters to minimize the amount of electrical interference.

\section{- Acoustic Errors}

Acoustic mistakes can emerge because of missing or falsely seen structures and are regularly because of blunders in gain setting Gain refers to the degree of amplification applied to all US signals reverting to the transducer. The too-high gain will make the picture too shining and obscure structures, while too little gain will darken the picture and may cause a structure to seem missing $[13,14]$

\subsection{Errors Due to Anatomical/Physiological Factors \\ - Obesity}

At whatever point a US beam crosses a tissue limit, a segment of the sound energy is reflected to the transducer making more echoes and further artifacts including speckling and clutter 
which are specific issues in the fat patient. Speckling artifact refers to interference patterns from echoes created by closely spaced reflectors and which are too little to even consider resolving.

The subsequent US picture seems to have a granular structure that obscures the underlying anatomy.

\section{- Oedema}

Tissue oedema offers various difficulties during ultrasoundguided nerve blocks. Diffuse oedema may intensify sound absorption and diminish the echo contrast that regularly exists among nerves and the encompassing tissues.

\section{- Muscle atrophy}

It is because of chronic myositis and muscle breakdown in the older is normally seen during USGRA the atrophied muscles reflect the US beam and are shown as hyperechoic structures. The inability of the US beam to sufficiently infiltrate atrophied muscle unclear structures which are deep [13, 14].

\subsection{Proven Techniques to Overcome \\ Challenges in The Ultrasound Imaging}

The challenges of ultrasound imaging can be resolved by utilizing various measures. The common techniques which are employed to get rid of these barriers are given below.

\section{Use of Filters}

Use of filters can reduce the speckle noise which can affect ultrasound imaging some of the commonly used filters are

- Linear filters

- Median filters

\section{- Linear Filters}

The liner filter may be utilized lower to lower speckle noise but the frequent problem with it is it tends to lower the noise at the cost of overly smoothing the images, and it suffers from the loss of the details such as small vessels and texture patterns because of blurring.

\section{- Median Filters}

Median filtering removes the impulsive artifacts in the region smaller than the half of the region. When speckle's size is larger than the filter's size, it remains unaltered. Versatile middle channels were examined, and the pixel worth was replaced by the weighted median of a nearby neighborhood whose size is resolved by the signal-to-noise ratio (SNR). This technique removes the speckle artifacts smaller than the half of the region size; but it also evacuates the fine details.

\section{Use of Multiscale Procedures}

In the multiscale procedure, a picture is disintegrated into different scales and numerous methodologies are utilized to take out the speckle noise in multiresolution domains, which is regularly called a "wavelet shrinkage technique." Wavelet shrinkage was applied to spot decrease of SAR pictures. The multiscale procedure is used to lessen the speckle noise which influences the ultrasound. In the multiscale procedure, a picture is disintegrated into different scales and numerous methodologies are utilized to take out the speckle noise in multiresolution domains, which is regularly called a "wavelet shrinkage technique. Multiscale techniques are grouped into two classes: Thresholding and Bayesian framework. Most thresholding techniques depend on soft thresholding denoising, known as wavelet shrinkage techniques $[15,16]$.

\section{RECENT ADVANCEMENTS IN ULTRASOUND PROCESSING AND THEIR TYPES}

In only 30 years, diagnostic ultrasound (US) machines have advanced from bulky and costly B-mode gantry frameworks that created coarse, static, bi-stable pictures to hand-held devices that are efficient to do high-resolution real-time greyscale and color Doppler imaging. Present-day ultrasound machines are completely computerized, which not only improves the signal to noise ratio of the arriving echoes but also offers great potential to the machine's efficiency concerning beam formation, signal processing, image display and archiving [17].

\subsection{D Ultrasound Imaging}

In recent years, ultrasound machines equipped for threedimensional imaging have been created. In these machines, many two-dimensional pictures are obtained by moving the probes over the body surface or rotating inserted probes. The two-dimensional scans are then integrated with specialized computer software to form 3D images [18].
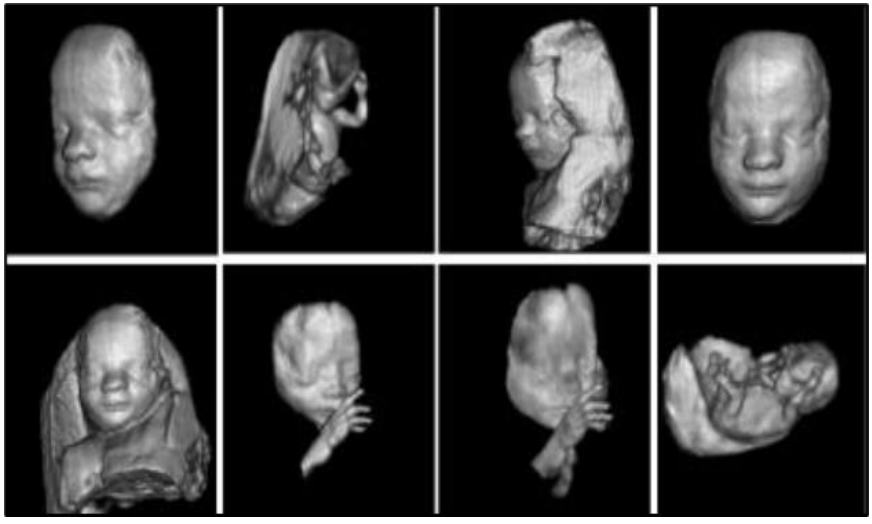

Figure 6: Images of the 3D ultrasound technique.

3D imaging enables the user to get a better visual of the organ which must be examined some of its most suitable uses are as follow.

- Checking the prostate gland for early assessment of tumors.

- Visualization for masses in the colon and rectum.

- Observation of a fetus for checking its development, especially for assessment of abnormal development of the face and limbs.

- Observation of blood flow in various organs or a fetus.

\subsection{Doppler Ultrasound}

Doppler ultrasound based on the Doppler Effect. At the point when the item which is reflecting the ultrasound waves is moving, it changes the recurrence of the echoes, making a higher recurrence if it is pushing toward the probe and a lower if it is moving aside from the probe. Changes in frequency rely on how quick the item is moving. Doppler ultrasound estimates the changes in the frequency of the echoes to ascertain how quickly an article is moving. Doppler ultrasound has been utilized for the most part to check the rate of blood flow through the heart and major arteries [18]. 


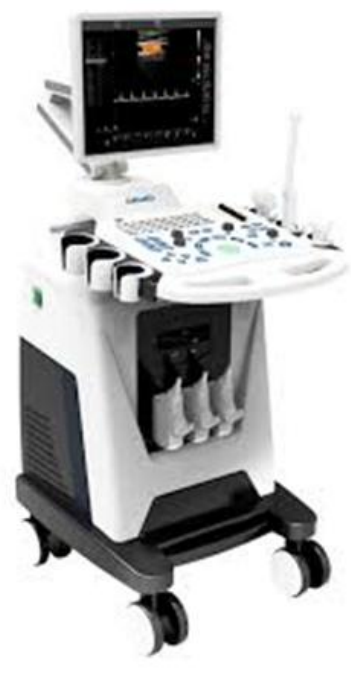

Figure 7: Doppler Ultrasound.

\section{RECENT COMPUTER-AIDED TECHNIQUES FOR ULTRASOUND IMAGE PROCESSING.}

Various advancements took place in the field of ultrasound imaging. Some of the recent advancements in this field are discussed below in figure 8 .

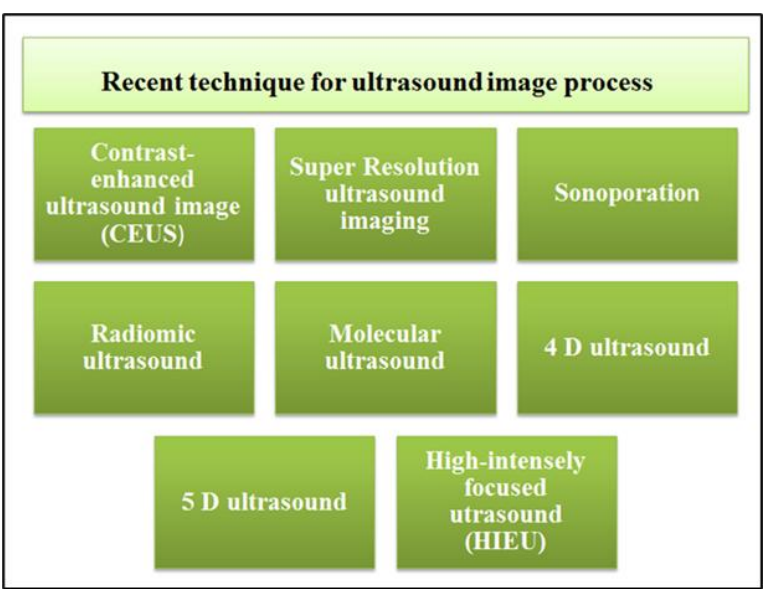

Figure 8: Recent techniques for ultrasound processing.

\subsection{Contrast-Enhanced Ultrasound Imaging (CEUS)}

For a long time, CEUS has been built up in clinical daily practice for characterization of suspected lesions in major organs, particularly the liver, and for identifying cardiovascular anomalies (e.g., utilizing echocardiography). In cardiovascular imaging, microbubbles are utilized mainly to intensify the signal in the vessel lumen and to visualize stenosis and aneurysms especially for the checking of endoleaks after endovascular aneurysm repair, CEUS demonstrated specificity and sensitivity like the contrastenhanced CT [17].

\subsection{Super-Resolution Ultrasound Imaging}

Like the 2014 Nobel Prize in chemistry, which was granted for breaking the diffraction barrier to produce super-resolution microscopy images, ultrasound imaging is making progress toward super-resolution to examine the microvasculature of tissues pioneering work of creating super-resolution pictures by following the way of microbubbles in vivo was published by Siepmann in 2011. The idea included the identification of individual microbubbles to produce super-resolution pictures by plotting their centroid positions and tracking their movement over time [18].

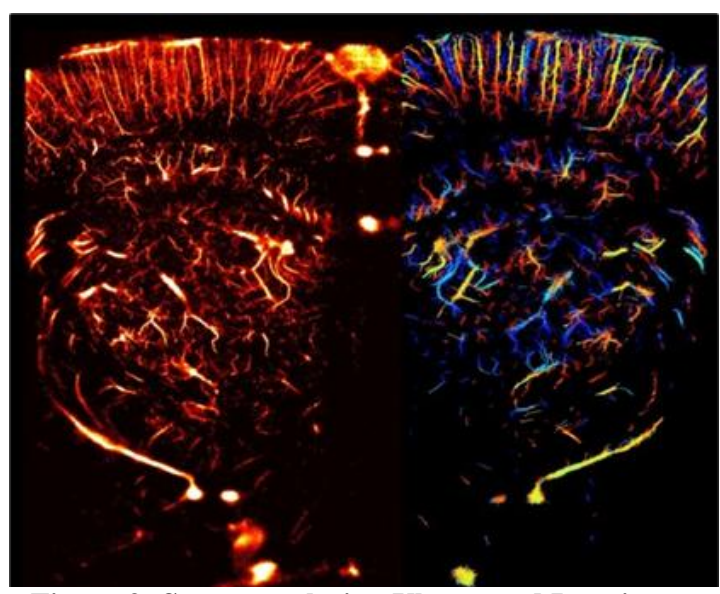

Figure 9: Super-resolution Ultrasound Imaging.

\subsection{Sonoporation}

Ultrasound is progressively used to improve the delivery of the drug to the pathologic site. In this specific situation, various methodologies can be investigated, related either to direct drug delivery or to indirect delivery of drugs [18].

\subsection{High-Intensity Focused Ultrasound (HIFU)}

HIFU can leads to local tissue heating, cavitation, and radiation forces, which can be utilized for many types of treatments, for example, tissue removal, image-guided drug delivery, and stimulation of immunity. Such treatments can be performed with high spatial precision utilizing transducers that are planned explicitly for therapeutic purposes and that permit focusing of ultrasound waves somewhere inside the body into a region around $1 \mathrm{~mm}$ in measurement, based upon the frequency and aperture of the transducer and on the tissue characteristics [19].

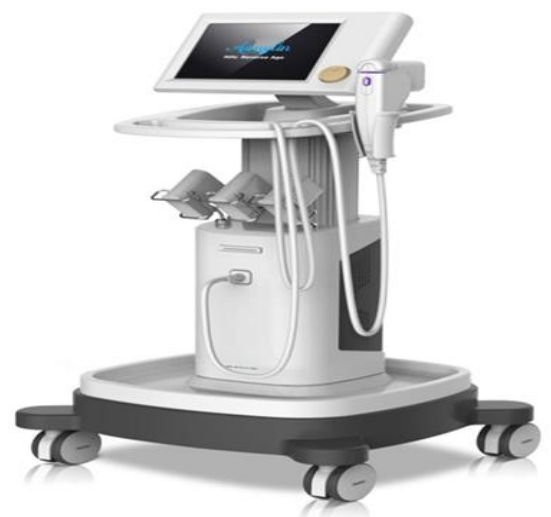

Figure 10: High-Intensity Focused Ultrasound (HIFU)

\subsection{D Ultrasound}

Ongoing improvements in 4D ultrasound imaging innovation enable clinicians to not only obtain good visual data but also quantitative information that can be utilized for making diagnosis and treatment. Advances in ultrasound make 4D ultrasound imaging quicker and less subject to the expertise of 
the operator, in this way opening up more research possibilities in the fields of data processing and visualization. As of now, 4D ultrasound is broadly utilized in the field of obstetrics and interventional radiology. The objective of 4D ultrasound is to get rid of the shortcomings presented by its predecessor technology and to be all the more clinically valuable as an imaging device [20].

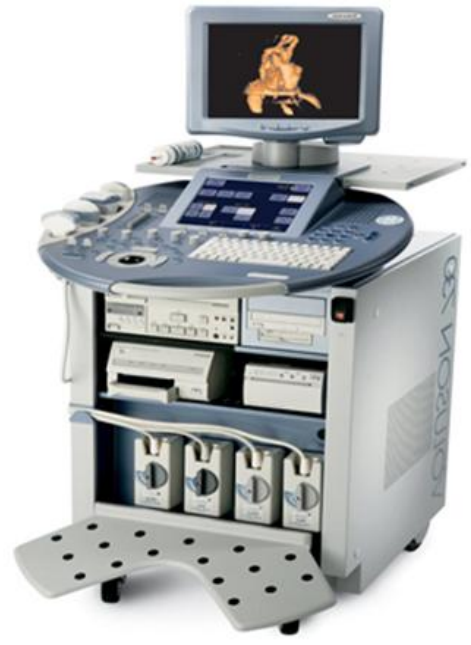

Figure 11: 4D ultrasound imaging.

\subsection{Molecular Ultrasound}

Lately, molecular ultrasound has risen as a promising new non-invasive imaging procedure for imaging biological processes at a molecular level. These ultra-sound contrast agents are decorated with ligands, for example, antibodies or small peptides that perceive receptor proteins engaged with a different disease. Gives Combined along with ultrasound imaging and the most recent transducer innovation, molecular ultrasound permits quantitative measurement of the molecular target with great sensitivity, which opens new applications for ultrasound including an early check of diseases, for example, cancer or atherosclerosis just as checking treatment impacts of novel medications, for example, anti-angiogenic drugs at the molecular level [21].

\section{IDEAL FEATURES OF AN INVEST PROCESSING ULTRASOUND OVER OTHER IMAGING TECHNIQUES [22,} 23]

Ultrasound diagnosis should possess various ideal features like some of the useful features are discussed below

- Cost-efficient: It should be cost-efficient like Diagnostic US is less costly compared to MRI.

- Patient-friendly: An ideal invest processing Ultrasound should be patient-friendly like the US is more userfriendly compared to MRI as the MRI scan can sometimes lead to claustrophobia, is not seen with US imaging.

- Dynamic imaging: The US also has the advantage of being a dynamic study. For example, in the case of the musculoskeletal ultrasound, the affected part can be imaged in real-time, asses for pathologic movement in tendon, bursa, muscles, or joints.

- Image process control: An ideal processing ultrasound must have better control while processing the image, like with ultrasound diagnostic, the patient at the same time gives feedback and useful information to the examiner during the dynamic examination.

- $\quad$ Fast track result: Since the diagnostic US examines in real-time, the patient and even the referring physician can receive results in control and immediately and then can outline a treatment strategy within the same visit.

- Radiation free technique: No ionizing radiation is required and hence the patient can be protected from the worst effects of radiation.

- Minimal anatomical and physiological errors: By using the US the Complications from surrounding structures can be avoided, in neonates in particularly vulnerable structures are very close to the areas we wish to insert our needle.

\section{DETECTION OF FETAL ANOMALIES USING INVEST PROCESSING ULTRASOUND [24]}

The prenatal diagnosis of inborn abnormalities with ultrasound builds on checking off a substantial departure of normal anatomy. This has been feasible in the second and third trimesters of pregnancy, and this accomplishment has made the diagnosis of birth defects one of the aims of presentday prenatal care. The meaning of the normal anatomy of the human fetus gives the basis for the assessment of birth defects at the initial stages of human development. In this way, the extent of prenatal diagnosis during embryonic life has been augmented by sonoembryology with a 3D ultrasound. One of the examples is explained below about central nervous system anomalies.

\subsection{Central Nervous System Anomalies}

Acrania, commonly seen by an early ultrasound scan, is described by partial or complete absence of the cranium. The shape of the cranium is can vary based on brain destruction. Figure 12 shows acrania complicated with cervical spina bifida, which is demonstrated by $3 \mathrm{D}$-reconstructed imaging. Holoprosencephaly can be detectable by careful observation of the midline and choroid plexus appearance.
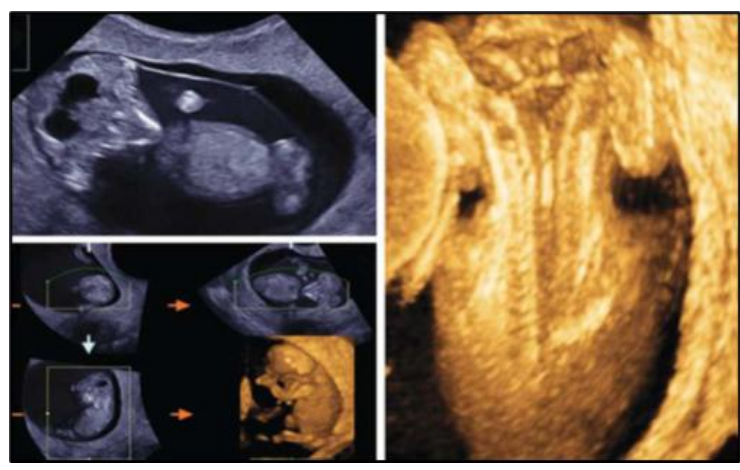

Figure. 12: Acrania with cervical spina bifida (craniorachischisis) at 11 weeks of gestation. Left upper: 2D image. Note the amniotic fluid is more turbid than the chorioamniotic cavity due to floating nerve tissue from the destroyed brain. Left lower; three orthogonal views and reconstructed image. Right: the 3D-reconstructed image of the cerebrospinal region. This fetus is complicated with acrania and cervical spina bifida, so-called craniorachischisis. 


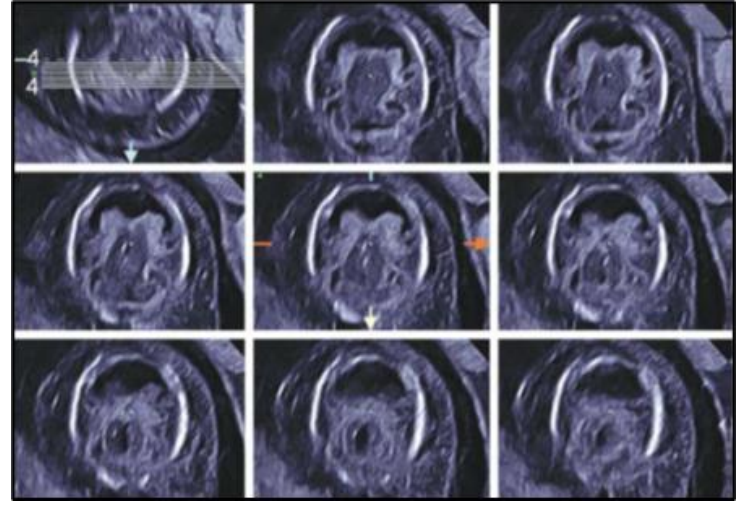

Figure. 13: Holoprosencephaly at 12 weeks of gestation. Tomographic ultrasound imaging shows a single ventricle due to nonseparated hemispheres

\section{THE LATEST U.S GRANTED PATENTS FOR ULTRASOUND}

The various patents have been granted to researchers for their ultrasound work. Some of the patents granted to inventors for their discovery are mentioned in the table 2 .

Table 2. The latest US granted patents for ultrasound along with summary, patent number, and name of the inventor

\begin{tabular}{|l|l|l|l|}
\hline $\begin{array}{l}\text { Summary of } \\
\text { Invention }\end{array}$ & Patent No. & Inventor & Ref \\
\hline $\begin{array}{l}\text { A researcher in the } \\
\text { united state gave the } \\
\text { unique design to an } \\
\text { ultrasound diagnostic } \\
\text { equipment. }\end{array}$ & D695,898 S & Chung et al. & 25 \\
\hline $\begin{array}{l}\text { Scientists invented the } \\
\text { handheld medical } \\
\text { diagnostic ultrasound } \\
\text { instrument which } \\
\text { provides ultrasound }\end{array}$ & D461,895 S & $\begin{array}{l}\text { Barnes et } \\
\text { wave transmission and } \\
\text { reception, electrical } \\
\text { signal analysis, and } \\
\text { display. }\end{array}$ & 26 \\
\hline $\begin{array}{l}\text { The inventor claimed } \\
\text { the ornamental design } \\
\text { for an ultrasound } \\
\text { diagnosis apparatus. }\end{array}$ & SSD626,236 & Ninomiya & 27 \\
\hline $\begin{array}{l}\text { The discoverer claimed } \\
\text { the unique design for a } \\
\text { probe for the } \\
\text { ultrasound diagnostic } \\
\text { apparatus. S }\end{array}$ & USD03,819 & M00n et al. & 28 \\
\hline $\begin{array}{l}\text { The inventor used the } \\
\text { curved reflector for } \\
\text { focusing Sound energy } \\
\text { reflected by a structure } \\
\text { being imaged a simple, } \\
\text { light, and power- } \\
\text { saving device was } \\
\text { made. 5,980,461 }\end{array}$ & Rajan et al. & 29 \\
\hline
\end{tabular}

\begin{tabular}{|l|l|l|l|}
\hline $\begin{array}{l}\text { The inventor gave the } \\
\text { ornamental design for } \\
\text { a medical ultrasound } \\
\text { transducer. }\end{array}$ & $\begin{array}{l}\text { Des. } \\
392,044\end{array}$ & $\begin{array}{l}\text { Mesaros et } \\
\text { al. }\end{array}$ & 30 \\
\hline $\begin{array}{l}\text { The more patent } \\
\text { claimed the unique } \\
\text { design for a probe for } \\
\text { the ultrasound } \\
\text { diagnostic apparatus. }\end{array}$ & $5,690,111$ & $\begin{array}{l}\text { Tsujino et } \\
\text { al. }\end{array}$ & 31 \\
\hline $\begin{array}{l}\text { The discoverer gave a } \\
\text { unique design for } \\
\text { probe of ultrasound } \\
\text { diagnosis apparatus. }\end{array}$ & S & & \\
\hline $\begin{array}{l}\text { A person filled patent } \\
\text { which gave the } \\
\text { ornamental design for } \\
\text { a medical ultrasound } \\
\text { device. S }\end{array}$ & & $\begin{array}{l}\text { Kanokogi et } \\
\text { al. }\end{array}$ & 32 \\
\hline $\begin{array}{l}\text { McConaghy, an } \\
\text { inventor who gave the } \\
\text { novel design to the } \\
\text { ultrasound machine } \\
\text { has also filed a patent } \\
\text { in Une United States. }\end{array}$ & $4,515,017$ & McConaghy & 34 \\
\end{tabular}

\section{SUMMARY AND CONCLUSION}

The congenital abnormality affects a large number of infants which leads to several birth defects and surviving children with physical, mental, and social handicaps are a significant burden on health and social services. With the development of modern prenatal screening and diagnostic techniques, a high detection rate of fetal abnormalities is possible. Diagnostic Ultrasound is one of the modern versatile tools in the detection of congenital abnormalities in the fetus. With the help of these techniques is now possible to prevent and manage these problems significantly. The addition of recent computer-aided techniques for ultrasound image processing in the future will allow for more accurate detection of an anomaly in the fetus. In any case, it is essential to acknowledge that not every single abnormality can be recognized by current screening methods suggestions should be taken from geneticists and fetal prescription subspecialists at a beginning period to ensure optimal management.

\section{ACKNOWLEDGMENT}

The author is grateful to her research guide Dr.S.S.Kawathekar for permitting her Ph.D. and providing guidance and facilities to write this review article.

\section{REFERENCES}

[1] Carovac, A., Smajlovic, F. and Junuzovic, D., 2011. Application of ultrasound in medicine. Acta Informatica Medica, 19(3), p.168..

[2] Mahatme, U., Archana, M., Dongre, S., Nakhate, A. and Tabhane, V., 2015, January. Applications of Ultrasound in Medical Science: A. In International Symposium on Ultrasonics (Vol. 22, No. 24).

[3] Salomon, L.J., Alfirevic, Z., Berghella, V., Bilardo, C., Hernandez- Andrade, E., Johnsen, S.L., Kalache, K., Leung, K.Y., Malinger, G., Munoz, H. and Prefumo, F., 2011. Practice guidelines for performance of the routine 
mid- trimester fetal ultrasound scan. Ultrasound in Obstetrics \& Gynecology, 37(1), pp.116-126.

[4] C., Alembik, Y., Dott, B. and Roth, M.P., 2002, July. Impact of prenatal diagnosis on livebirth prevalence of children with congenital anomalies. In Annales de genetique (Vol. 45, No. 3, pp. 115-121). Elsevier Masson.

[5] Chitty, L.S., Hunt, G.H., Moore, J. and Lobb, M.O., 1991. Effectiveness of routine ultrasonography in detecting fetal structural abnormalities in a low risk population. British Medical Journal, 303(6811), pp.11651169.

[6] Arslan, E., Büyükkurt, S., Sucu, M., Özsürmeli, M., Misırlığlu, S., Demir, S.C. and Evrüke, İ.C., 2018. Detection of major anomalies during the first and early second trimester: Single-center results of six years. Journal of the Turkish German Gynecological Association, 19(3), p.142.

[7] Syngelaki, A., Chelemen, T., Dagklis, T., Allan, L. and Nicolaides, K.H., 2011. Challenges in the diagnosis of fetal non chromosomal abnormalities at 11-13 weeks. Prenatal diagnosis, 31(1), pp.90-102.

[8] Athira, P.K. and Mathew, L.S., 2015. Fetal anomaly detection in ultrasound image. International Journal of Computer Applications, 975, p.8887.

[9] Sprawls, P., 1993. Physical principles of medical imaging. Gaithersburg: Aspen Publishers.

[10] Lutz, H. and Buscarini, E. eds., 2011. Manual of diagnostic ultrasound (Vol. 2). World Health Organization.

[11] Parker, S.E., Mai, C.T., Canfield, M.A., Rickard, R., Wang, Y., Meyer, R.E., Anderson, P., Mason, C.A., Collins, J.S., Kirby, R.S. and Correa, A., 2010. Updated national birth prevalence estimates for selected birth defects in the United States, 2004-2006. Birth Defects Research Part A: Clinical and Molecular Teratology, 88(12), pp.1008-1016.

[12] Hans, J., Lammens, M. and Hori, A., 2014. Clinical neuroembryology: development and developmental disorders of the human central nervous system. Springer.

[13] Henderson, M. and Dolan, J., 2016. Challenges, solutions, and advances in ultrasound-guided regional anaesthesia. Bja Education, 16(11), pp.374-380..

[14] Loughna, P., 2008. Congenital abnormalities: failure to detect and treat. The Obstetrician \& Gynaecologist, 10(1), pp.33-37.

[15] Guo, Y., Cheng, H.D., Tian, J. and Zhang, Y., 2009. A novel approach to speckle reduction in ultrasound imaging. Ultrasound in medicine \& biology, 35(4), pp.628-640.

[16] Gupta, S., Chauhan, R.C. and Sexana, S.C., 2004. Wavelet-based statistical approach for speckle reduction in medical ultrasound images. Medical and Biological Engineering and computing, 42(2), pp.189-192.

[17] Harvey, C.J., Pilcher, J.M., Eckersley, R.J., Blomley, M.J. and Cosgrove, D.O., 2002. Advances in ultrasound. Clinical radiology, 57(3), pp.157-177.

[18] Frye, R.A., Hsieh, S.J. and Palomares, J.B.D.G., 2011, May. Use of infrared imaging for investigation of chicken embryo development. In Thermosense: Thermal Infrared Applications XXXIII (Vol. 8013, p. 801306). International Society for Optics and Photonics.

[19] Welkoborsky, H.J., 2019. Future Developments of Sonography. In Ultrasonography of the Head and Neck (pp. 349-356). Springer, Cham.

[20] Obruchkov, S., 2008. The technology and performance of $4 \mathrm{D}$ ultrasound. Critical Reviews ${ }^{\mathrm{TM}}$ in Biomedical Engineering, 36(4).

[21] Deshpande, N., Needles, A. and Willmann, J.K., 2010. Molecular ultrasound imaging: current status and future directions. Clinical radiology, 65(7), pp.567-581.

[22] Lento, P.H. and Primack, S., 2008. Advances and utility of diagnostic ultrasound in musculoskeletal medicine. Current reviews in musculoskeletal medicine, 1(1), pp.24-31.

[23] Sahlgren, C., Meinander, A., Zhang, H., Cheng, F., Preis, M., Xu, C., Salminen, T.A., Toivola, D., Abankwa, D., Rosling, A. and Karaman, D.Ş., 2017. Tailored approaches in drug development and diagnostics: from molecular design to biological model systems. Advanced Healthcare Materials, 6(21), p.1700258.

[24] Pooh, R.K. and Kurjak, A., 2012. Threedimensional/four-dimensional sonography moved prenatal diagnosis of fetal anomalies from the second to the first trimester of pregnancy. DSJUOG, 6, pp.376-390.

[25] Chung, Y.M., Lee, J.Y., Park, H.Y. and Kim, J.H., Samsung Electronics Co Ltd, 2013. Ultrasound diagnostic equipment. U.S. Patent Application $29 / 431,394$

[26] Barnes, S.A. and Wing, G.T., Fujifilm Sonosite Inc, 2002. Handheld medical diagnostic ultrasound instrument. U.S. Patent Application 29/140,638.

[27] Ninomiya, A., Kasai, Y., Tsuneo, K. and Inoue, M., Hitachi Healthcare Manufacturing Ltd, 2010. Ultrasound diagnosis apparatus. U.S. Patent Application 29/309,857.

[28] Moon, J.P., Ran, S.M. and Kim, U., Samsung Medison Co Ltd, 2014. Probe for ultrasound diagnostic apparatus. U.S. Patent Application 29/464,115.

[29] Rajan, S.D., Rajan and Subramaniam D., 1999. Ultrasound imaging apparatus for medical diagnostics. U.S. Patent 5,980,461.

[30] Mesaros, R., Henderson, R.W., Park, W.J., Ruvolo, K.A. and Marshall, J.L., Acuson Corp, 1998. Medical ultrasound transducer. U.S. Patent Application 29/063,128.

[31] Tsujino, H., Toshiba Corp, 1997. Ultrasound diagnostic apparatus. U.S. Patent 5,690,111.

[32] Kanokogi, T. and Mori, O., Hitachi Healthcare Manufacturing Ltd, 2011. Probe of ultrasound diagnosis apparatus. U.S. Patent Application 29/365,823.

[33] Kim, K.S., Ahn, C.Y., Hyun, S.M. and Kwon, J.C., Samsung Electronics Co Ltd, 2014. Medical ultrasound device. U.S. Patent Application 29/427,605.

[34] McConaghy, R.F., Advanced Technology Laboratories Inc, 1985. Oscillating ultrasound scanhead. U.S. Patent $4,515,017$. 